\title{
IMPACT OF DIETARY MANGANESE OXIDE NANOPARTICLES ON BIOCHEMICAL PARAMETERS OF CLARIAS GARIEPINUS
}

\author{
SARA R. THABET ${ }^{1}$; ABDEL-GALIL, M.A.A. ${ }^{2}$; OSMAN, A. S $^{3}$; NAGWA S. \\ AHMED ${ }^{4}$ AND M.A. MOUSA ${ }^{5}$ \\ ${ }^{1}$ Demonstrator of Biochemistry, Fac. Vet. Med., Sohag University \\ ${ }^{2}$ Professor of Fish Diseases and Management, Fac. Vet. Med., Sohag University \\ ${ }^{3}$ Lecturer of Biochemistry, Fac. Vet. Med., Sohag University \\ ${ }^{4}$ Professor of Biochemistry, Med., Sohag University \\ ${ }^{5}$ Assist. Prof. of Nutrition and Clinical Nutrition Fac. Vet. Med., Sohag University
}

Received: 31 December 2020; Accepted: 30 March 2021

\begin{abstract}
This study was conducted on 150 (one hundred and fifty) Clarias gariepinus to investigate the blood lipids (triglycerides and cholesterol), kidney functions (creatinine and urea), liver functions (ALT - AST - ALP - LDH), antioxidants (CAT - SOD - GPx) and growth performance (body weight and weight gain). The study was designed by dividing the fish into 3 groups: Group 1: (Control Group), Group 2: (2.4 mg manganese oxide nanoparticles/kg ration) and Group 3 (1.2 mg manganese oxide nanoparticles/kg ration). Samples were collected on day 15, 30, 45 and 60 of the experiment and blood samples were collected for serum separation. The results of this study indicated that the $2^{\text {nd }}$ group exhibited a significant and progressive decrease in triglycerides, cholesterol, ALT, AST, ALP, LDH, creatinine and urea at all experiment times compared to the control group. Shifting to the antioxidants, the $2^{\text {nd }}$ and $3^{\text {rd }}$ groups showed a significant increase in CAT, SOD and GPx levels in the serum compared with the control group at day 60 of the experiment. Concerning the results of growth performance, both groups reflected a significant improvement in body weight and weight gain compared with the control group.
\end{abstract}

\section{INTRODUCTION}

Aquaculture is a globally important industry that provides essential food to a growing world population. Very rapid developments have been occurred in aquaculture sector of Egypt in recent years and exhibited the strongest growth of any

Corresponding author: SARA R. THABET

E-mail address: sararoshedy0@gmail.com

Present address: Demonstrator of Biochemistry, Fac. Vet. Med., Sohag University fisheries-related activity in the country (Soliman and Yacout, 2016).

The African catfish (Clarias gariepinus) are freshwater fish of great importance as they grow quickly, attain a large size, and are edible fish. They can withstand wide range of environmental conditions, including severe temperatures, as well as low oxygen (Abdel-Hakim and Abdel-Nasser (2001)).

Manganese (Mn) is a necessary micronutrient for reproduction, prevention of diseases, and growth of fish and terrestrial animals (Veeramani et al., 2013 and 
Asaikkutti et al., 2016). Manganese (Mn) is an essential trace element that is found in all the tissues and plays a vital physiological role in metabolism of the proteins, carbohydrates, and lipids (Tufarelli and Laudadio, 2017).

Mineral nanoparticles are proving more effective than their bulk counterparts as feed supplements, in improving the growth and health of cultured fish. Higher level of effectiveness is interestingly observed with lower doses of nanomaterials which make them even more cost and material effective than the bulk materials. Higher doses of nanomaterials were found to be detrimental to fish growth and health (Chris et al., 2018). Nanoparticles in aquatic ecosystems are taken by fish and transported to the tissues and organs through the blood (Handy et al., 2008). Supplementations of Mn-oxide NPs significantly increased the activity of antioxidant defense system and metabolic activities such as SOD, CAT, GOT and GPT (Asaikkutti et al., 2016).

This work aims to study the biochemical effects of manganese oxide (nanoparticles) feed additives for the cultured Clarias gariepinus including triglycerides, cholesterol, creatinine, urea, alanine aminotransferase (ALT), aspartate aminotransferase (AST), alkaline phosphatase (ALP), lactate dehydrogenase (LDH)) and antioxidants as catalase (CAT), superoxide dismutase (SOD) and glutathione peroxidase (GPx) in addition to the fish body performance (Body weight and weight gain).

\section{MATERIALS AND METHODS}

The current experiment was conducted in a Fish Research Laboratory, Fish Diseases and Management department, Faculty of veterinary Medicine, Sohag University.

Materials:

\section{A) Experimental Fish:}

One hundred and fifty catfish (Clarias gareipinus) (150) were obtained from Rashid, Behera governorate. They left for an initial adaptation period of two weeks before experiment. The final fish body weight post acclimation was $90 \pm 10$ gram.

\section{B) Experimental Mn $\quad$ oxide nanoparticles:}

Manganese oxide nanoparticles were purchased from Nanotech company (Dreamland, El-Wahaat Road, 6th October, Giza, Egypt).

\section{C) Fish management:}

The acclimated Clarias gariepinus were subdivided to 3 groups, each group consists of 50 fish and was stocked in a separate tank (200L capacity). Each tank was supplied with continuous air source and constant daily partial water change $(30 \%$ of the water/24 hours). Fish Feeding commenced 24 hours after distribution of fish into the experimental tanks at $3 \%$ of body weight. The prepared diets were fed twice-daily between the hours of 8 and 9 in the morning, and 4 to 5 in the evening.

\section{D) Experimental grouping:}

The experiment was designed in 3 groups to finalize the aims of this study: Group 1 (Control group): Fishes received basic diet according to NRC (2.4 mg manganese from manganese oxide/ kg diet). Group 2 (MnO nanoparticles dose - (MnO NP -d): Fishes received basic diet with addition of $2.4 \mathrm{mg}$ manganese from $\mathrm{MnO}$ nanoparticles/ $\mathrm{kg}$ diet instead of $2.4 \mathrm{mg}$ manganese from manganese oxide / $\mathrm{kg}$ ration. Group $3(\mathrm{MnO}$ nanoparticles half dose - ( $\mathrm{MnO} \mathrm{NP}-\mathrm{hd})$ : Fishes received basic diet with addition of $1.2 \mathrm{mg}$ manganese from $\mathrm{MnO}$ nanoparticles/ $\mathrm{kg}$ diet instead of $2.4 \mathrm{mg}$ manganese from manganese oxide / $\mathrm{kg}$ ration. 
Table 1: Ingredients $(\mathrm{kg})$ and chemical composition of basal and experimental diets for Clarias gariepinus

\begin{tabular}{cccc}
\hline $\begin{array}{c}\text { Ingredients } \\
(\mathbf{k g} / \mathbf{1 0 0} \mathbf{~ k g})\end{array}$ & $\begin{array}{c}\text { Group (1) } \\
\text { (Control / basal diet) }\end{array}$ & $\begin{array}{c}\text { Group (2) } \\
(\text { MnO NP -d })\end{array}$ & $\begin{array}{c}\text { Group (3) } \\
\text { (MnO NP -hd })\end{array}$ \\
\hline Soybean meal & 40 & 40 & 40 \\
\hline Corn & 28 & 28 & 28 \\
\hline Sunflower meal & 20 & 20 & 20 \\
\hline Fish meal & 10 & 10 & 10 \\
\hline calcium carbonate & 0.7 & 0.7 & 0.7 \\
\hline Sodium chloride & 0.3 & 0.3 & 0.3 \\
\hline Vitamin C & 0.025 & 0.025 & 0.025 \\
\hline Magnesium & 0.004 & 0.004 & 0.004 \\
\hline Manganese & 0.24 & 0.24 & 0.12 \\
\hline Slack & 0.731 & 0.731 & 0.851 \\
\hline
\end{tabular}

\section{Methods:}

\section{1) Blood Sampling:}

Blood samples were collected from caudal blood vessels into three clean, dry, sterile and labeled centrifuged tubes from five fishes of each group in the indicating time at $15^{\text {th }}, 30^{\text {th }}, 45^{\text {th }}$ and $60^{\text {th }}$ days from the start of the experiment. The tubes without anticoagulant were left to clot and the serum was obtained by centrifugation at 4000 r.p.m for 10 minutes. The clear supernatant serum was collected and stored at $-20^{\circ} \mathrm{C}$ until further biochemical analysis.

\section{2) Biochemical Parameters \\ Determination:}

The levels of triglycerides and cholesterol were detected according to (Naghsh and Kazemi, 2014), creatinine and urea (Tietz et $a l .$, 1994), as well as activities of aspartate aminotransferase (AST), alanine aminotransferase (ALT) (Tietz.,1994), alkaline phosphatase and lactate dehydrogenase (LDH) (Ognik et al., 2018) at $15,30,45$ and $60^{\text {th }}$ day of experimental period and antioxidants (catalase, glutathione peroxidase and superoxide dismutase (Zhang et al., 2016)) levels at $60^{\text {th }}$ day only were determined by using commercial kits (Chema diagnostica and spectrum), Egypt.

\section{Statistical analysis:}

Experimental data subjected to several statistical analyses from which means \pm standard errors were calculated using the Graph-Pad Prism (GraphPad software, San Diego, CA, USA). Differences were tested for significance by one-way analysis of variance. Differences $(\mathrm{P} \leq 0.05)$ among treatments were tested using Tukey's Honest significant difference test.

\section{RESULTS}

The results obtained in this study were statistically analyzed, the mean and standard errors values of the biochemical parameters (triglyceride, cholesterol, ALT, AST, ALP, LDH, creatinine and urea), antioxidant enzymes (CAT, SOD and GPx) and body performance of the Clarias gariepinus fish in the treated $\mathrm{MnO}$ nanoparticles and control groups were presented in tables 2 to 8 . 
Table 2: Effects of Manganese oxide nanoparticles on serum triglycerides and cholesterol $(\mathrm{mg} / \mathrm{dl})$ in Clarias gariepinus

\begin{tabular}{ccccccc}
\hline \multirow{2}{*}{$\begin{array}{c}\text { Experimental } \\
\text { periods }\end{array}$} & \multicolumn{3}{c}{ Triglycerides } & \multicolumn{3}{c}{ Cholesterol } \\
\cline { 2 - 7 } & $\begin{array}{c}\text { Group 1 } \\
\text { Control }\end{array}$ & $\begin{array}{c}\text { Group 2 } \\
\text { MnO NP-d }\end{array}$ & $\begin{array}{c}\text { Group 3 } \\
\text { MnO NP-hd }\end{array}$ & $\begin{array}{c}\text { Group1 } \\
\text { control }\end{array}$ & $\begin{array}{c}\text { Group 2 } \\
\text { MnO NP-d }\end{array}$ & $\begin{array}{c}\text { Group 3 } \\
\text { MnO NP-hd }\end{array}$ \\
\hline \multirow{2}{*}{$\mathbf{1 5}$ days } & 160.03 & 148.13 & 140.67 & 190 & 187.67 & 182.36 \\
& $\pm 1.9^{\mathrm{a}}$ & \pm 1.93 & $\pm 1.94^{\mathrm{b}}$ & $\pm 14.07^{\mathrm{a}}$ & \pm 12.33 & $\pm 25.39^{\mathrm{b}}$ \\
\hline \multirow{2}{*}{$\mathbf{3 0}$ days } & 158.34 & 147.67 & 138.38 & 187.37 & 186.33 & 179.67 \\
& $\pm 15.28^{\mathrm{a}}$ & \pm 19.03 & $\pm 3.49^{\mathrm{b}}$ & $\pm 2.40^{\mathrm{a}}$ & \pm 2.89 & $\pm 5.23^{\mathrm{c}}$ \\
\hline \multirow{2}{*}{$\mathbf{4 5}^{*}$ days } & 161.47 & 145 & 136.21 & 185.67 & 180.67 & 175.86 \\
& $\pm 17.45^{\mathrm{a}}$ & \pm 9.00 & $\pm 5.97^{\mathrm{c}}$ & $\pm 3.38^{\mathrm{a}}$ & $\pm 3.33^{\mathrm{b}}$ & $\pm 8.83^{\mathrm{c}}$ \\
\hline \multirow{2}{*}{$\mathbf{6 0}^{*}$ days } & 159.67 & 138.65 & 113.63 & 180.3 & 173.6 & 168.14 \\
& $\pm 10.58^{\mathrm{a}}$ & $\pm 6.74^{\mathrm{b}}$ & $\pm 10.58^{\mathrm{c}}$ & $\pm 2.04^{\mathrm{a}}$ & $\pm 3.36^{\mathrm{b}}$ & $\pm 4.71^{\mathrm{b}}$ \\
\hline
\end{tabular}

a, b, c, d Means on the same row with different superscripts are significantly different $(\mathrm{P}<0.05)$.

Table 3: Effects of Manganese oxide nanoparticles on serum creatinine and urea $(\mathrm{mg} / \mathrm{dl})$ in Clarias gariepinus

\begin{tabular}{ccccccc}
\hline \multirow{2}{*}{$\begin{array}{c}\text { Experimental } \\
\text { periods }\end{array}$} & \multicolumn{3}{c}{ Creatinine } & \multicolumn{3}{c}{ Urea } \\
\cline { 2 - 7 } & Group 1 & Group 2 & Group 3 & Group 1 & Group 2 & Group 3 \\
Control & MnO NP-d & MnO NP-hd & control & MnO NP-d & MnO NP-hd \\
\hline 15 days & 0.36 & 0.29 & 0.27 & 8.9 & 8.65 & 7.95 \\
& $\pm 0.02^{\mathrm{a}}$ & \pm 0.06 & $\pm 0.08^{\mathrm{b}}$ & $\pm 1.16^{\mathrm{a}}$ & \pm 0.9 & $\pm 0.95^{\mathrm{b}}$ \\
\hline 30 days & 0.36 & 0.30 & 0.25 & 8.71 & 8.37 & 7.82 \\
& $\pm 0.03^{\mathrm{a}}$ & \pm 0.03 & $\pm 0.03^{\mathrm{b}}$ & $\pm 0.57^{\mathrm{a}}$ & \pm 0.33 & $\pm 0.66^{\mathrm{b}}$ \\
\hline $\mathbf{4 5}$ days & 0.33 & 0.27 & 0.24 & 8.62 & 8.02 & 7.76 \\
& $\pm 0.06^{\mathrm{a}}$ & $\pm 0.01^{\mathrm{b}}$ & $\pm 0.05^{\mathrm{c}}$ & $\pm 0.08^{\mathrm{a}}$ & $\pm 0.1^{\mathrm{a}}$ & $\pm 0.33^{\mathrm{c}}$ \\
\hline $\mathbf{6 0}$ days & 0.28 & 0.23 & 0.21 & 8.53 & 7.85 & 7.09 \\
& $\pm 0.03^{\mathrm{a}}$ & $\pm 0.01^{\mathrm{b}}$ & $\pm 0.06^{\mathrm{c}}$ & $\pm 0.09^{\mathrm{a}}$ & $\pm 0.52^{\mathrm{b}}$ & $\pm 0.33^{\mathrm{d}}$ \\
\hline
\end{tabular}

${ }^{a, b, c, d}$ Means on the same row with different superscripts are significantly different $(\mathrm{P}<0.05)$.

Table 4: Effects of Manganese oxide nanoparticles on serum ALT and AST (IU/L) in Clarias gariepinus

\begin{tabular}{|c|c|c|c|c|c|c|}
\hline \multirow{2}{*}{$\begin{array}{l}\text { Experimental } \\
\text { periods }\end{array}$} & \multicolumn{3}{|c|}{ ALT } & \multicolumn{3}{|c|}{ AST } \\
\hline & $\begin{array}{c}\text { Group } 1 \\
\text { Control }\end{array}$ & $\begin{array}{l}\text { Group } 2 \\
\text { MnO NP-d }\end{array}$ & $\begin{array}{l}\text { Group } 3 \\
\text { MnO NP-hd }\end{array}$ & $\begin{array}{c}\text { Group } 1 \\
\text { control }\end{array}$ & $\begin{array}{c}\text { Group } 2 \\
\text { MnO NP-d }\end{array}$ & $\begin{array}{c}\text { Group } 3 \\
\text { MnO NP-hd }\end{array}$ \\
\hline 15 days & $\begin{array}{l}59.32 \\
\pm 1.61\end{array}$ & $\begin{array}{l}58.94 \\
\pm 4.49\end{array}$ & $\begin{array}{l}57.27 \\
\pm 2.74\end{array}$ & $\begin{array}{c}139.9 \\
\pm 1.36^{\mathrm{a}}\end{array}$ & $\begin{array}{c}138.14 \\
\pm 2.16^{\mathrm{a}}\end{array}$ & $\begin{array}{c}132.12 \\
\pm 1.05^{\mathrm{b}}\end{array}$ \\
\hline 30 days & $\begin{array}{c}59.05 \\
\pm 1.52^{a}\end{array}$ & $\begin{array}{c}57.69 \\
\pm 1.20^{b}\end{array}$ & $\begin{array}{c}56.83 \\
\pm 1.15^{b}\end{array}$ & $\begin{array}{c}136.31 \\
\pm 2.02^{a}\end{array}$ & $\begin{array}{c}135.67 \\
\pm 1.20^{a}\end{array}$ & $\begin{array}{c}127.33 \\
\pm 1.43^{b}\end{array}$ \\
\hline 45 days & $\begin{array}{c}59 \\
\pm 2.72 \mathrm{a}\end{array}$ & $\begin{array}{c}56.43 \\
\pm 2.90^{\mathrm{b}}\end{array}$ & $\begin{array}{c}55.46 \\
\pm 2.66^{b}\end{array}$ & $\begin{array}{c}136 \\
\pm 2.82^{a}\end{array}$ & $\begin{array}{r}129.36 \\
\pm 2.66^{b}\end{array}$ & $\begin{array}{c}123.1 \\
\pm 2.79^{c}\end{array}$ \\
\hline 60 days & $\begin{array}{c}59.07 \\
\pm 1.04^{\mathrm{a}}\end{array}$ & $\begin{array}{c}56.2 \\
\pm 1.92 \text { b }\end{array}$ & $\begin{array}{c}54.03 \\
\pm 2.08 \mathrm{~b}\end{array}$ & $\begin{array}{c}135.9 \\
\pm 1.84^{\mathrm{a}}\end{array}$ & $\begin{array}{c}121.02 \\
\pm 1.29 \mathrm{~b}\end{array}$ & $\begin{array}{r}117.3 \\
\pm 1.67^{c}\end{array}$ \\
\hline
\end{tabular}

$\overline{\mathrm{a}, \mathrm{b}, \mathrm{c}, \mathrm{d}}$ Means on the same row with different superscripts are significantly different $(\mathrm{P}<0.05)$. 
Table 5: Effects of Manganese oxide nanoparticles on serum ALP and LDH (IU/L) in Clarias gariepinus

\begin{tabular}{|c|c|c|c|c|c|c|}
\hline \multirow[b]{2}{*}{$\begin{array}{l}\text { Experimental } \\
\text { periods }\end{array}$} & \multicolumn{3}{|c|}{ ALP } & \multicolumn{3}{|c|}{ LDH } \\
\hline & $\begin{array}{c}\text { Group } 1 \\
\text { Control }\end{array}$ & $\begin{array}{c}\text { Group } 2 \\
\text { MnO NP-d }\end{array}$ & $\begin{array}{c}\text { Group } 3 \\
\text { MnO NP-hd }\end{array}$ & $\begin{array}{c}\text { Group } 1 \\
\text { control }\end{array}$ & $\begin{array}{c}\text { Group } 2 \\
\text { MnO NP-d }\end{array}$ & $\begin{array}{c}\text { Group } 3 \\
\text { MnO NP-hd }\end{array}$ \\
\hline 15 days & $\begin{array}{r}59.9 \\
\pm 1.38^{a} \\
\end{array}$ & $\begin{array}{r}54.51 \\
\pm 1.71^{c} \\
\end{array}$ & $\begin{array}{r}53.04 \\
\pm 1.76^{c} \\
\end{array}$ & $\begin{array}{c}672 \\
\pm 14.85^{a} \\
\end{array}$ & $\begin{array}{r}668.6 \\
\pm 14.31^{b} \\
\end{array}$ & $\begin{array}{c}665.05 \\
\pm 12.38^{\mathrm{b}} \\
\end{array}$ \\
\hline 30 days & $\begin{array}{r}58.67 \\
\pm 1.37^{\mathrm{a}} \\
\end{array}$ & $\begin{array}{r}53.89 \\
\pm 1.76^{b} \\
\end{array}$ & $\begin{array}{r}50.39 \\
\pm 3.03^{c} \\
\end{array}$ & $\begin{array}{c}669.37 \\
\pm 21.24^{\mathrm{a}}\end{array}$ & $\begin{array}{c}663.24 \\
\pm 12.81^{\mathrm{b}}\end{array}$ & $\begin{array}{c}662.8 \\
\pm 21.89^{b} \\
\end{array}$ \\
\hline 45 days & $\begin{array}{c}58.38 \\
\pm 1.23^{\mathrm{a}}\end{array}$ & $\begin{array}{c}53.6 \\
\pm 1.05^{b}\end{array}$ & $\begin{array}{c}47.08 \\
\pm 0.33^{\mathrm{d}}\end{array}$ & $\begin{array}{c}670 \\
\pm 12.41^{a}\end{array}$ & $\begin{array}{c}659 \\
+13.12^{b}\end{array}$ & $\begin{array}{c}656.79 \\
\pm 12.54^{b}\end{array}$ \\
\hline 60 days & $\begin{array}{c}59.3 \\
\pm 1.91^{a}\end{array}$ & $\begin{array}{c}51.68 \\
\pm 2.96^{b}\end{array}$ & $\begin{array}{l}46.03 \\
\pm 2.40^{c}\end{array}$ & $\begin{array}{c}671.33 \\
\pm 14.11^{a}\end{array}$ & $\begin{array}{c}652.31 \\
\pm 20.73^{b}\end{array}$ & $\begin{array}{c}649.67 \\
\pm 20.62^{c}\end{array}$ \\
\hline
\end{tabular}

$\overline{\mathrm{a}, \mathrm{b}, \mathrm{c}, \mathrm{d}}$ Means on the same row with different superscripts are significantly different $(\mathrm{P}<0.05)$.

Table 6: Effects of Manganese oxide nanoparticles on serum antioxidants (U/L) in Clarias gariepinus at day 60

\begin{tabular}{cccc}
\hline & $\begin{array}{c}\text { Group 1 } \\
\text { Control }\end{array}$ & $\begin{array}{c}\text { Group 2 } \\
\text { MnO NP -d }\end{array}$ & $\begin{array}{c}\text { Group 3 } \\
\text { MnO NP-hd }\end{array}$ \\
\hline \multirow{2}{*}{ Catalase } & $161^{\mathrm{c}}$ & 167.3 & 177.28 \\
\cline { 2 - 4 } & $\pm 2.89^{\mathrm{c}}$ & $\pm 5.1^{\mathrm{b}}$ & $\pm 4.29^{\mathrm{a}}$ \\
\hline \multirow{2}{*}{ SOD } & 227.34 & 243.67 & 248.33 \\
\cline { 2 - 4 } & $\pm 6.5^{\mathrm{d}}$ & $\pm 2.13^{\mathrm{b}}$ & $\pm 2.88^{\mathrm{a}}$ \\
\cline { 2 - 4 } & & & 364.1 \\
\hline \multirow{2}{*}{ Glutathione peroxidase } & 337.39 & 358.73 & $\pm 1.64^{\mathrm{a}}$ \\
\cline { 2 - 4 } & $\pm 4.8^{\mathrm{d}}$ & $\pm 2.1^{\mathrm{b}}$ & \\
\hline
\end{tabular}

a, b, c, d Means on the same row with different superscripts are significantly different $(\mathrm{P}<0.05)$.

Table 7: Effects of Manganese oxide nanoparticles on body weight and development (gram) of Clarias gariepinus

\begin{tabular}{cccc}
\hline \multirow{2}{*}{ Experimental periods } & \multicolumn{3}{c}{ Body weight } \\
\cline { 2 - 4 } & $\begin{array}{c}\text { Group 1 } \\
\text { Control }\end{array}$ & $\begin{array}{c}\text { Group 2 } \\
\text { MnO NP-d }\end{array}$ & $\begin{array}{c}\text { Group 3 } \\
\text { MnO NP-hd }\end{array}$ \\
\hline Initial weight (Starting day) & 89.6 & 90.22 & 88.24 \\
\hline \multirow{2}{*}{$\mathbf{1 5}$ days } & 97.65 & 105.26 & 110.58 \\
& $\pm 1.03^{\mathrm{c}}$ & $\pm 1.46^{\mathrm{b}}$ & $\pm 1.22^{\mathrm{a}}$ \\
\hline \multirow{2}{*}{$\mathbf{3 0}$ days } & $109.2^{\mathrm{y}}$ & 129.08 & 137.25 \\
& $\pm 2.18^{\mathrm{d}}$ & $\pm 1.5^{\mathrm{b}}$ & $\pm 1.63^{\mathrm{a}}$ \\
\hline \multirow{2}{*}{$\mathbf{4 5}$ days } & 121.91 & 150.55 & 173.55 \\
& $\pm 3.65^{\mathrm{c}}$ & $\pm 2.36^{\mathrm{b}}$ & $\pm 1.12^{\mathrm{a}}$ \\
\hline \multirow{2}{*}{$\mathbf{6 0}^{2}$ days } & 137.91 & 178.25 & 216.4 \\
& $\pm 3.20^{\mathrm{c}}$ & $\pm 11.50^{\mathrm{b}}$ & $\pm 13.64^{\mathrm{a}}$ \\
\hline $\mathrm{a}, \mathrm{b}, \mathrm{c}, \mathrm{d}$ & Means on the same row with different superscripts are significantly different $(\mathrm{P}<0.05)$.
\end{tabular}


Table 8: Effects of Manganese oxide nanoparticles on weight gain (gram) of Clarias gariepinus

\begin{tabular}{cccc}
\hline \multirow{2}{*}{ Experimental periods } & \multicolumn{3}{c}{ Weight gain } \\
\cline { 2 - 4 } & $\begin{array}{c}\text { Group 1 } \\
\text { control }\end{array}$ & $\begin{array}{c}\text { Group 2 } \\
\text { MnO NP-d }\end{array}$ & $\begin{array}{c}\text { Group 3 } \\
\text { MnO NP- hd }\end{array}$ \\
\hline \multirow{2}{*}{ First 15 days } & 8.05 & 15.04 & 22.34 \\
& \pm 1.98 & $\pm 1.50^{\mathrm{b}}$ & $\pm 2.22^{\mathrm{a}}$ \\
\hline \multirow{2}{*}{$\mathbf{1 6}$ - 30 days } & 11.55 & 23.82 & 26.67 \\
& \pm 2.9 & $\pm 2.16^{\mathrm{ab}}$ & $\pm 2.39^{\mathrm{a}}$ \\
\hline \multirow{2}{*}{$\mathbf{3 1}$ - 45 days } & 12.71 & 21.47 & 36.3 \\
& $\pm 1.47^{\mathrm{d}}$ & $\pm 2.75^{\mathrm{c}}$ & $\pm 1.48^{\mathrm{a}}$ \\
\hline \multirow{2}{*}{$\mathbf{4 6}$ - 60 days } & $16^{\mathrm{d}}$ & 17.7 & 42.85 \\
& $\pm 1.95^{\mathrm{d}}$ & $\pm 1.43^{\mathrm{d}}$ & $\pm 1.54^{\mathrm{a}}$ \\
\hline \multirow{2}{*}{ Total (Cumulative) } & 48.31 & 88.03 & $128.16^{2}$ \\
\hline
\end{tabular}

\section{DISCUSSION}

This work was carried out to evaluate the biochemical parameters including (triglyceride, cholesterol, creatinine, urea, ALT, AST, ALP and LDH), antioxidant enzymes (CAT, SOD and GPx) as well as body performance (body weight and weight gain) of Clarias gariepinus fish fed $\mathrm{MnO}$ nanoparticles supplemented diets.

The results of this study showed that the serum triglycerides and cholesterol levels significantly and progressively decreased ( $\mathrm{p}$ $\leq 0.05)$ from the day 15 to the day 60 in the $3^{\text {rd }}$ group comparing to the control. There is no significant difference in the values of triglyceride in the $2^{\text {nd }}$ group at the day 15 , 30 and 45 of the experiment, but significantly decreased at the day 60 , but the cholesterol showed a significant decrease at the day 45 and 60 of the experiment compared to the control group. In agreement with our results, Oladipo et al., (2017) showed that exposure to lowlevel of Mn reduced the serum triglyceride levels in rats. These results may be attributed to the increase in lipid metabolism (Lall, 2002) as $\mathrm{Mn}$ is participated in lipid metabolism through lipid catabolism (McTaggart, 2006 and Park et al., 2017).
The current results indicated that the serum creatinine and urea of Clarias gariepinus significantly decreased $(\mathrm{p} \leq 0.05)$ from the day 15 to the end of experiment (day 60) in the $3^{\text {rd }}$ group compared with the control one, while it is significantly and progressively decreased at the day 45 and 60 only in the $2^{\text {nd }}$ group compared with the control.

These results were in accordance with the finding reported by Ognik et al. (2018) who found a decreased creatinine levels after reducing $\mathrm{Mn}$ supplementation in the diet of turkeys from 100 to 50 and then to 10 $\mathrm{mg} / \mathrm{kg}$ of feed, irrespective of the form of Mn used. The possible reason for urea decrease is conversion of uric acid (which produced in fish from endogenous and exogenous purine nucleotides as well as catabolism of proteins by purines) to urea in the liver and a lesser extent in the kidneys and mainly excreted through gills (Lee et al., 2008). So, it is not increased in serum.

Shifting to the results of liver function tests, it was reported that the serum ALT and AST levels significantly and progressively decreased $(p \leq 0.05)$ in the $2^{\text {nd }}$ and $3^{\text {rd }}$ evaluated Clarias gariepinus groups at the day 30,45 and 60 of the experiment compared to controls. 
Our findings were in harmony with that detected by Singh et al. (2013) who noticed that these enzymes activity are increased in serum as the dose increased, after repeated treatment with $\mathrm{MnO}-\mathrm{NPs}$ in male and female rats. These findings indicate a better process of liver activity by adding these minor doses of nanoparticles, and this may be related to the increased antioxidant performance of these nanoparticles, cells membrane stabilization, and cell damage prevention (Niu et al., 2014).

The serum ALP and LDH levels significantly and progressively decreased ( $p$ $\leq 0.05)$ in the $2^{\text {nd }}$ and $3^{\text {rd }}$ treated groups compared to control one at day $15,30,45$ and 60 .

Ognik et al. (2018) who reported that the levels of ALP and LDH enzymes increased in the tissue homogenates of Mn high doses treated turkeys (100 to $50 \mathrm{mg} / \mathrm{kg}$ of feed) which may be referred to the extent of hepatocellular injury leading to possible leakage of these enzymes into the bloodstream.

Concerning the serum antioxidants results of our study, the catalase, SOD and Glutathione peroxidase levels (U/L) significantly increased in $2^{\text {nd }}$ and $3^{\text {rd }}$ investigated groups at the end of experiment (day 60) compared to control. These results can be explained in the light of the participation of $\mathrm{Mn}$ in numerous biochemical reactions as an integral part of metalloenzymes and as an enzyme activator, in addition to the Mn-SOD enzymatic cofactor reactions which protects cells against damage caused by free radicals by catalyzing the one-electron reduction of peroxide anion to hydrogen peroxide (Ognik et al., 2018).

Inconsistent with our results, Asaikkutti et al., (2016) reported that the antioxidants enzymatic activity (SOD and CAT) showed no significant $(\mathrm{P}>0.05)$ alterations in prawns fed with $3.0-18 \mathrm{mg} / \mathrm{kg}$ of Mn-oxide NPs supplemented diets.

Concerning the growth performance parameters, the results of final body weight displayed a significant improvement $(\mathrm{p} \leq$ 0.05 ) in the $2^{\text {nd }}$ and the $3^{\text {rd }}$ groups compared with control and the final weight gain also displayed significant increase in these investigated groups compared to the control group.

These findings came in accordance with the results of Nguyen et al. (2008), Pan et al. (2008), Tan et al. (2012) and Liu et al. (2013) who recorded that $\mathrm{Mn}$ supplementation significantly improved the growth in larvae of red sea bream and juveniles of several species. The enhanced fish body growth and gain may be attributed to the bioavailability $\mathrm{Mn}$ from MnO-NPs administration and also its action on internal metabolism which improves the activates of fish digestive enzymes and these enhance the food consumption and food conversion (Srinivasan et al., 2016 and 2017 and Asaikkutti et al., 2016).

IN CONCLUSION, the results of this study referred to Manganese oxide nanoparticles at $1.2 \mathrm{mg} / \mathrm{kg}$ in ration significantly boosted the blood lipids profile of Clarias gariepinus fish including triglycerides and cholesterol, augment the kidney (Creatinine and Urea) and liver functions (ALT, AST, ALP and LDH), improved antioxidant capacity (CAT, SOD and GPx) and enhanced the body performance including body weight and body gain of the treated fish.

\section{REFERENCES}

Abdel-Hakim, N.F. and Abdel-Nasser, G. (2001): The effect of different dietary protein levels on the reproductive performance of Clarias gariepinus bloodstock. J. Egypt. Acad. Soc. Environ. Develop., (B-Aquacult., 1(1): 19-28. 
Asaikkutti, A.; Bhavan P.S.; Vimala K.; Karthik, M. and Cheruparambath, $P$. (2016): Dietary supplementation of green synthesized manganese-oxide nanoparticles and its effect on growth performance, muscle composition and digestive enzyme activities of the giant freshwater prawn Macrobrachium rosenbergii, J. Trace Elem. Med. Biol. (35), 7-17.

Chris, O.; Singh, N.B. and Agarwal, A. (2018): Nanoparticles as feed supplement on Growth behavior of Cultured Catfish (Clarias gariepinus) fingerlings. Mater. Tod. (5): 90769081.

Handy, R.D.; Owen, R. and Valsami-Jones, E. (2008): The ecotoxicology of nanoparticles and nanomaterials: current status, knowledge gaps, challenges, and future-needs. Ecotoxicology (17): 315-325.

Lall, S.P. (2002): The minerals. In: Halver JE, Hardy RW (eds) Fish nutrition, 3rd edn. Academic Press Inc, San Diego, 259-308.

Lee, S.; Lee, JH. and Bai, SC. (2008): Effects of different levels of dietary selenium (Se) on growth, tissue Se accumulations and histopathological changes in black seabream, Acanthopagrus schlegeli. AsianAustralas J. Anim. Sci. (21): 17941799.

Liu, X.F.; Zhang, L.M.; Guan, H.N.; Zhang, Z.W. and $X u, S . W$. (2013): Effects of oxidative stress on apoptosis in manganese-induced testicular toxicity in cocks. Food Chem. Toxi. (60): 168-176.

Mc Taggart, S.J. (2006): Isoprenylated proteins. Cell Mol Life Sci.; 63(3): 255-67.

Naghsh, N. and Kazemi, Sh. (2014): Effect of Nano-magnesium Oxide on Glucose Concentration and Lipid Profile in Diabetic Laboratory Mice. Iranian J. Pharm. Sci., 10(3): 63- 68.

Nguyen, V.T.; Satoh, S.; Haga, Y.; Fushimi, H. and Kotani, T. (2008): Effect of zinc and manganese supplementation in Artemia on growth and vertebral deformity in red sea bream (Pagrus major) larvae. Aquac., (285): 184192.

Niu, H.; Jia, Y.; Hu, P.; Meng, Z. and Lei, J. (2014): Effect of dietary vitamin $\mathrm{E}$ on the growth performance and nonspecific immunity in subadult turbot (Scophthalmus maximus). Fish Shellfish Immunol., (41): 501-506.

NRC (National Research Council) (1993): Nutrient Requirements of Fish. National Acadey press, Washington DC, USA.

Ognik, K.; Kozłowski, K.; Stępniowska, A.; Szlazak, R.; Tutaj, K.; Zduńczyk, Z. and Jankowski, J. (2018): The effect of manganese nanoparticles on performance, redox reactions and epigenetic changes in turkey tissues. Anim. page 1 of 8 .

Oladipo, O.O.; Ayo, J.O.; Ambali, S.F., Mohammed, B. and Aluwong, $T$. (2017): Dyslipdemia induced by chronic low dose co-exposure to lead, cadmium and manganese in rats: the role of oxidative stress. Environ Toxicol Pharmacol.; (53): 199-205.

Pan, L.; Zhu, X.; Xie, S.; Lei, W.; Han, D. and Yang, $Y$. (2008): Effects of dietary manganese on growth and tissue manganese concentrations of juvenile gibel carp, Carassius auratus gibelio. Aquac. Nutr. J., (14): 459463.

Park, J.; Zielinski, M.; Magder, A.; Tsantrizos, Y.S. and Berghuis, A.M. (2017): Human farnesyl pyrophosphate synthase is allosterically inhibited by its own product. Nat Commun.; (8):14132.

Singh, S.P.; Kumari, M.; Kumari, S.I.; Rahman, M.F.; Mahboob, M. and Grover, $\quad$ P. $\quad$ (2013): $\quad$ Toxicity assessment of manganese oxide micro and nanoparticles in Wistar rats after 28 days of repeated oral exposure. J. Appl. Toxi., (33): 1165-1179. 
Soliman, N.F. and Yacout, D.M.M. (2016): Aquaculture in Egypt: status, constraints and potentials. Springer Intern. Publishing Switzerland, Aquacult. Int. DOI 10.1007/s10499016-9989-9.

Srinivasan, V.; Bhavan, P.S.; Rajkumar, G.; Satgurunathan, T. and Muralisankar, T. (2016): Effects of dietary iron oxide nanoparticles on the growth performance, biochemical constituents and physiological stress responses of the giant freshwater prawn Macrobrachium rosenbergii postlarvae. Int. J. Fish. Aquat. Stud., 4 (2): 170-182.

Srinivasan, V.; Bhavan, P.S.; Rajkumar, G.; Satgurunathan, T. and Muralisankar T. (2017): Dietary supplementation of magnesium oxide (MgO) nanoparticles for better survival and growth of the freshwater prawn Macrobrachium rosenbergii post-larvae. Biol. Trace Elem. Res., 177 (1): 196-208.

Tan, X.Y.; Xie, P.; Luo, Z.; Lin, H.Z.; Zhao, $Y . H$. and $X i$, W.Q. (2012): Dietary manganese requirement of juvenile yellow catfish Pelteobagrus fulvidraco, and effects on whole body mineral composition and hepatic intermediary metabolism. Aquac., (326): $68-73$.

Tietz, N.W. (1994): Textbook of Clin. Chem., Second Edition, BurtisAshwood. pp 1271-1281.

Tufarelli, V. and Laudadio, V. (2017): Manganese and its role in poultry nutrition: an overview. J. Exp. Biol. Agric. Sci., (5): 749-754.

Veeramani, H.; Aruguete, D.; Monsegue, N.; Murayama, M.; Dippon, U.; Kappler, A. and Hochella, M.F. (2013): Low Temperature Green Synthesis of Multivalent Manganese Oxide Nanowires, ACSSustain. Chem. Eng., (1):1070-1074.

Zhang, C.X.; Huang, F.; Li, J.; Wang, L.; Song, K. and Mai, K.S. (2016): Interactive effects of dietary magnesium and vitamin $\mathrm{E}$ on growth performance, body composition, blood parameters and antioxidant status in Japanese seabass (Lateolabrax japonicus) fed oxidized oil. Aquac. Nutr., (22): 708-722.

\section{أثر تغذية أكسيد المنجنيز متناهي الصغر على الخواص البيوكيميائية في سمك القرموط \\ سارة رشدي ثابت ، محمد عبل العزيز أحد عبل الجليل ، أحد السيل عصدان ، نجوى سبي أحمد ، محد عبدالله موسى} E-mail: sararoshedy0@gmail.com Assiut University web-site: www.aun.edu.eg

أجريت هذه الدراسة لتقييم تأثير إضافة اكسيد المنجنيز متناهي الصغر على بعض التون التغيرات البيوكيميائية وإنزيمات

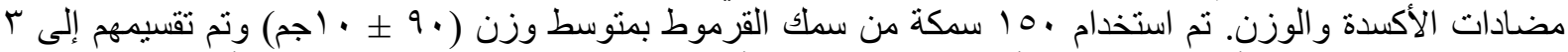

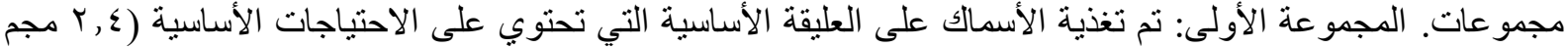

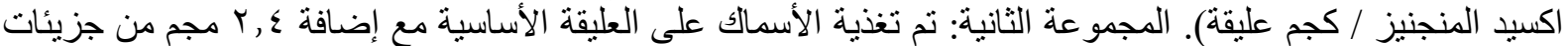

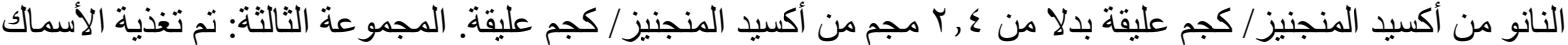

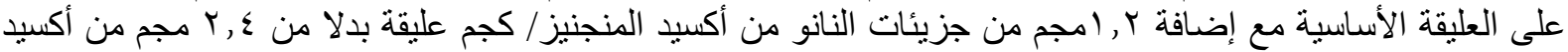

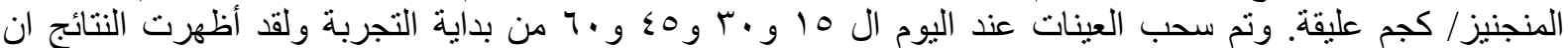

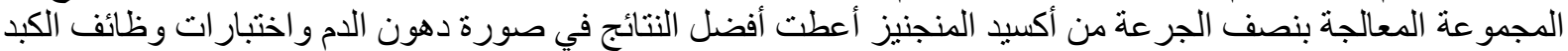

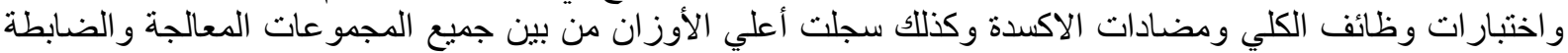

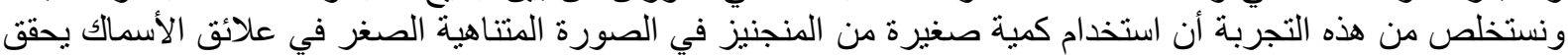
نتائج أفضل على مستوى صحة اسماك القرموط الته ومعدلات النمو. 